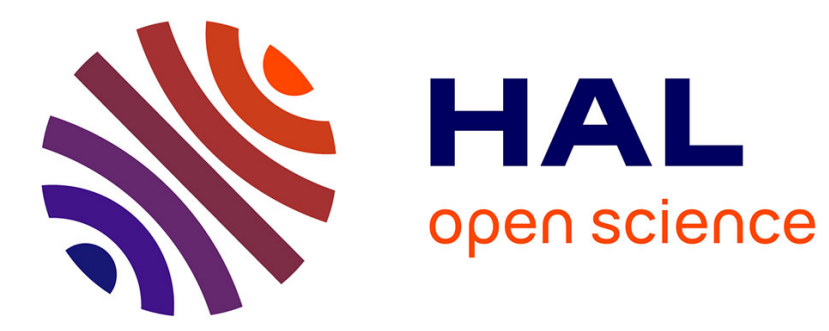

\title{
Non-Linear Pattern of International Capital Flows
} Ly Dai Hung

\section{- To cite this version:}

Ly Dai Hung. Non-Linear Pattern of International Capital Flows. 2018. hal-01935151

\section{HAL Id: hal-01935151 \\ https://hal.science/hal-01935151}

Preprint submitted on 26 Nov 2018

HAL is a multi-disciplinary open access archive for the deposit and dissemination of scientific research documents, whether they are published or not. The documents may come from teaching and research institutions in France or abroad, or from public or private research centers.
L'archive ouverte pluridisciplinaire HAL, est destinée au dépôt et à la diffusion de documents scientifiques de niveau recherche, publiés ou non, émanant des établissements d'enseignement et de recherche français ou étrangers, des laboratoires publics ou privés. 


\title{
Non-Linear Pattern of International Capital Flows
}

\author{
Hung Ly-Dai*
}

October 8, 2018

\begin{abstract}
We establish one non-linear pattern of international capital flows by building up one two-country OLG economy. With symmetric growth and asymmetric interest rate wedges across countries, net total capital inflows are either decreasing or increasing on productivity growth rate. However, with asymmetric growth and asymmetric wedges, they follow one U-shaped curve by first decreasing and then increasing on growth. The turning point of the curve is built on world average growth rate and wedges. Our proposed model can provide an explanation for inconsistencies between theories (i.e, Lucas paradox, up-hill capital flows, and allocation puzzle) about the pattern of international capital flows.
\end{abstract}

Keywords: Allocation Puzzle, Capital Flows, Financial Frictions, Productivity Growth. JEL Classifications: F15, F36, F43.

*Email: hunglydai@gmail.com. Address: office 221, Centre d'Économie de la Sorbonne, 106 - 112 Boulevard de l'Hôpital, 75013 Paris, France. And office V8-137, Universitätsstrasse 25, 33615 Bielefeld, Germany. I am grateful for helpful comments by Cuong Le Van, Jean-Bernard Chatelain, Ha Huy Thai, Ngoc-Sang Pham, two anonymous reviewers, and participants at the economics seminars in Paris School of Economics, and Bielefeld Graduate School of Economics and Management. The author acknowledges financial support by the European Commission in the framework of the European Doctorate in Economics - Erasmus Mundus (EDEEM). 


\section{Introduction}

The past decades witness a diversification on the pattern of international capital flows across the developing and advanced economies (Figure 1.0.1). On one hand, the exporters of capital can be the advanced economies with low growth rates (e.g., Japan (JPN), Germany (DEU), Netherlands $(\mathrm{NLD})$ ) or emerging economies with the high growth rates (e.g., China (CHN), Korea (KOR), Singapore (SGP)). On the other hand, the importers of capital can be the slow-growing advanced economies (e.g., United States (USA), United Kingdoms (GBR), and Australia (AUS)) or the fast-growing emerging economies (e.g., Cyprus (CYP), Thailands (THA), Pakistan (PAK)). These observations raise the concern over the dependence of net total capital inflows on the productivity growth rate.

Figure 1.0.1: International Capital Flows by Countries

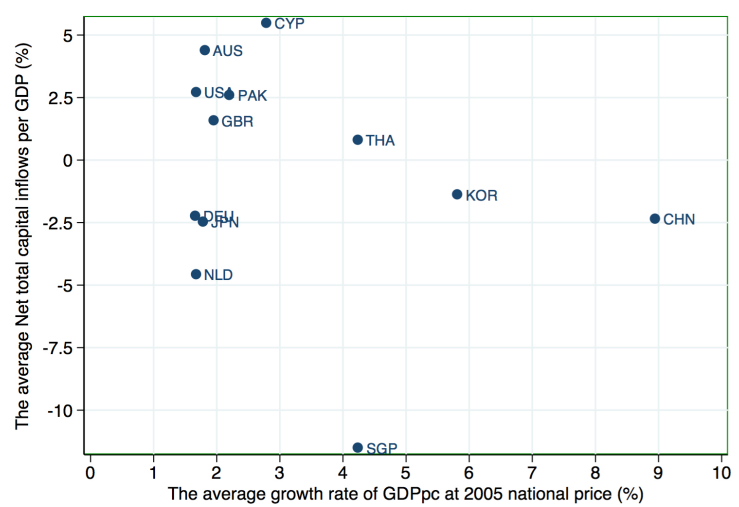

Notes: All variables are averaged over 1980-2013. The net total capital inflows are the negative value of current account as percentage of GDP and GDPpc is real output-side GDP per capita at constant 2005 national price. More details are on the section on Data description.

The Neo-Classical growth model (Solow (1956))predicts that one economy with high growth rate will invest more and receive the inflows of capital. Recent empirical evidence about up-hill capital flows (Prasad, Rajan, and Subramanian (2007)), however, demonstrates that the fastgrowing economies tend to experience the outflows of capital. Our paper rationalizes both of these arguments by showing that the pattern of international capital inflows is non-linear: the capital inflows are decreasing and then, increasing on the productivity growth rate. Therefore, the up-hill pattern exists for low growth rates but the Neo-Classical growth model works for high growth rates.

By building up one two-country overlaping generation (OLG) economy, we show that international capital flows follow a non-linear pattern rather than a linear pattern. Each country differs by both the productivity growth and the interest rate wedges. At autarky, the interest rate depends on domestic growth rate and wedges. At integration, one world interest rate is 
equalized across countries and depends on the world average growth rate and wedges. Since capital flows into the country which has a higher interest rate at autarky than at integration, the net total capital inflows are one function of growth rates and wedges. By setting the partial derivative of the net total capital inflows with respect to growth to be zero, the model ends up with one threshold which determines the pattern of capital flows. Only if the growth rate is over the threshold, the capital inflows are increasing on growth, as implied by the Neo-Classical growth model. These suggest that the interaction between the growth and the wedges formulates the non-linearity of the pattern of capital flows.

Our paper belongs to the literature about the dependence pattern of international capital flows on the productivity growth (see Gourinchas and Rey (2014) for a recent survey). Lucas [1 (1990) raises the question why capital does not flow from rich to poor economies, which have higher marginal product of capital due to capital scarcity. He argues that the phenomenon is caused by the difference between institutional quality and productivity level across rich and poor economies. Recently, Gourinchas and Jeanne (2013) postulate that, for Non-OECD ${ }^{1}$ economies, the inflows of capital are decreasing on the productivity growth. They label this phenomenon as allocation puzzle, which is contradictory to the implication by the Neo-Classical growth model. Aguiar and Amador (2011) explain the puzzle by showing that, only in one lowly distorted political environment, governments in countries with high growth rates are willing to reduce their sovereign debt quickly and therefore, generate the outflows of capital. However, Alfaro, Kalemli-Ozcan and Volosovych (2014) find that, for one large sample covering both OECD and Non-OECD economies, capital inflows are still increasing on the productivity growth.

Different from the aforementioned papers, we argue that capital flows can be either increasing or decreasing on the productivity growth, within the framework of symmetric growth and asymmetric wedges across countries. Then, both of the allocation puzzle theory and the Neo-Classical growth model can be involved in explaining the pattern of capital flows. The non-linearity of capital flows is similar to the theory raised by Benhima (2013). By introducing uninsurable idiosyncratic investment risk in the Neo-Classical growth model with international trade in bonds, they show that the net total capital inflows are increasing on growth for creditors, but decreasing for debtors. The initial position of net foreign assets is also crucial to shape the pattern of international capital flows according to Kraay and Ventura (2000). However, in our paper, the value of domestic interest rate wedges, which capture the financial frictions, forms one condition in determining the pattern of capital flows. As a result, both creditors and debtors can have the same pattern of international capital flows as long as their wedges satisfy the same condition.

The contention in the literature is that the dependence pattern of capital flows on growth is linear. However, for one rich environment of both asymmetric growth and asymmetric wedges

\footnotetext{
${ }^{1}$ Organisation for Economic Co-operation and Development.
} 
across countries, our theory establishes that capital flows follows a non-linear pattern which is both decreasing and increasing on the productivity growth. Therefore, the allocation puzzle can co-exist with the implication of the Neo-Classical growth model on the international capital flows pattern. The turning point is built up on world average growth and wedges. Specifically, one economy with an improvement in growth can switch from an decreasing pattern applied for low growth rates to an increasing pattern held for high growth rates. In brief, the non-linearity of capital flows is one distinguished feature in our model.

There are also other two-country models to account for flows of capital from developing to advanced economies. Gertler and Rogoff (1990) propose that, since the asymmetric information problem is less severe in the rich than in the poor countries, the former has a lower domestic loan rate. Therefore, the rich countries have a higher investment demand, and receive the capital from the poor countries to finance the domestic investment. According to Boyd and Smith (1997), a rich economy has higher investment since its high income can afford for the agency cost induced by the asymmetric information on lending. Matsuyama (2004) adds that by having one higher initial capital stock, one rich country converges to a higher steady state capital accumulation level than one poor economy and therefore, attracts more capital inflows.

These aforementioned papers, however, consider only the pattern of capital flows for either developing or advanced economies by focusing on the investment demand as the underlying ground for capital flows from developing to advanced economies. Consequently, their frameworks are silent on the high saving supplies in developing economies, which are another crucial driver of capital flows (Bernanke (2005)).

We, on the other hand, construct a model which can also account for the pattern of international capital flows for both advanced and developing economies. By controlling for the asymmetric wedges across countries, both advanced and developing economy can have the same pattern of capital flows. The reason is that the pattern of international capital flows depends on whether the domestic growth passes over one country-specific threshold. By being over the threshold, one economy belongs to the region in which capital inflows are increasing on productivity growth no mater whether it is an advanced or a developing economy. In short, our proposed model can cover the pattern of capital flows for a wide range of economies.

Moreover, our approach stresses the misalignment of both saving supply and investment demand as drivers of capital flows. Specifically, the heterogeneous interest rate wedges can generate different saving supplies and investment demands across countries. For instance, a developing economy with low saving wedge and/or high investment wedge will have high savings and/or low investment; due to excess savings, the capital therefore will flow out of that country. The interaction of saving and investment is another distinguished feature of our model.

Some recent papers employ other ingredients rather than productivity growth to analyze international capital flows. Farhi, Caballero and Gourinchas (2008) focus on the supply of 
financial assets which advanced economies can manufacture much more than their developing counterparts and claim that capital flows from developing to advanced economies in seeking the assets as store of wealth. Coeurdacier, Guibaud and Jin (2015) concentrate on the interaction between borrowing constraint and demographic change. In particular, the aging population in China raises savings by middle-age people more than borrowings by young people. The case, however, is reversal in the United States. Then, the capital flows from China to United States to finance the latter's huge borrowing. The international financial frictions such as capital controls and domestic frictions such as labor income taxation are employed on Ohanian, Restrepo-Echavarria and Wright (2015) to analyze the capital flows. Their calibration shows that the domestic distortions plays a greater role in accounting for the combination of high growth and low inflows of capital.

Our paper differs to these aforementioned papers by interpreting the central role of productivity growth rate on shaping the pattern of international capital flows. The value of growth still determines whether one economy experiences an increase or a decrease of net total capital inflows. Moreover, our analysis of growth rate also takes into account other ingredients such as the interest rate wedges to fully characterize the pattern of capital flows.

The paper is structured as follows. After the introduction, section (2) lays out the model and characterizes the equilibrium. Section (3) presents the core theoretical results on the pattern of international capital flows across countries. Finally section (4) concludes.

\section{Theory}

Our model is one world economy includes two countries: Home and Foreign. Each country is populated with the overlapping generations of households, one representative firm and one international bank. Each household living for two periods supplies one unit of labor when young and retires when old. All firms use the same technology to produce homogeneous good. The banks receive savings from the young agents and make loans to the firms.

There are three different kinds of interest rates, including deposit rate, rental rate, and lending rate. Deposit rate is the household's rate of return on savings as deposits in banks. Rental rate of capital is the firm's cost of borrowing loans from banks. Lending rate clears the intern-bank market, which equalizes aggregate supply of loans by banks and demand for deposits by households.

Other features of our model are standard. Preferences and production technologies have the same structure and parameter values across countries. Good is used for consumption and investment, and is traded freely and costlessly. Capital is free mobile but labor is immobile across countries. Firms are subject to changes in the country-specific productivity levels and labor forces. 


\subsection{Economy}

We first describe the environment of economy and then, analyze the interest rates at autarky equilibrium. The difference of autarky lending rates across countries determines the direction of international capital flows at integration equilibrium. Variables with asterisk $(*)$ present the Foreign country.

\subsubsection{Production}

Let $K_{t}$ denote the capital stock at the beginning of period $t$, and $N_{t}$ the total labor input employed in period $t$. The output is produced by Constant-Return-to-Scale technology:

$$
Y_{t}=\left(K_{t}\right)^{\alpha}\left(A_{t} N_{t}\right)^{(1-\alpha)}
$$

whereby $0<\alpha<1$, and $A_{t}$ is country-specific productivity.

The factor markets are perfect competitive so that each factor, capital and labor, earns its marginal product. Given the rental rate of capital $\left(R_{t}\right)$, the capital stock, the wage rate per unit of labor and the corresponding output are:

$$
\begin{aligned}
K_{t} & =\left(\frac{\alpha}{R_{t}}\right)^{1 /(1-\alpha)} A_{t} N_{t} \\
w_{t} & =(1-\alpha)\left(\frac{\alpha}{R_{t}}\right)^{\alpha /(1-\alpha)} A_{t} \\
Y_{t} & =\left(\frac{\alpha}{R_{t}}\right)^{\alpha /(1-\alpha)} A_{t} N_{t}
\end{aligned}
$$

The capital stock is fully depreciated and is augmented by investment $I_{t-1}$, by the law of motion: $\left(K_{t}=I_{t-1}\right)$. Given the rental rate of capital at the next period $\left(R_{t+1}\right)$, the investment demand by firm at time $t$ is given by determined by the capital stock at time $(t+1)$.

$$
I_{t}=K_{t+1}=\left(\frac{\alpha}{R_{t+1}}\right)^{1 /(1-\alpha)} A_{t+1} N_{t+1}
$$

Let $g_{t}^{A}$ and $g_{t}^{N}$ denote the exogenous growth rate of productivity and of the size of consecutive cohorts, respectively, so that: $A_{t}=\left(1+g_{t}^{A}\right) A_{t-1}$ and $N_{t}=\left(1+g_{t}^{N}\right) N_{t-1}$.

\subsubsection{Consumption}

One household born in period $t$ earns the competitive wage rate $w_{t}$. Let $c_{t}^{y}$ and $c_{t+1}^{o}$ denote the consumption of an agent when young and old respectively. The lifetime utility of a household born in period $t$ is:

$$
U_{t}=u\left(c_{t}^{y}\right)+\beta u\left(c_{t+1}^{o}\right)
$$

The preference follows one log function: $u(c)=\ln (c)$ and the discount factor $\beta$ satisfies $0<\beta<1$. In Appendix (C), we show that the main results are not dependent on the log utility 
function.

Let $s_{t}$ denote the saving at the end of period $t$ of an agent born at $t$. The sequence of budget constraints is as follows:

$$
\begin{aligned}
c_{t}^{y}+s_{t} & =w_{t} \\
c_{t+1}^{o} & =R_{t+1}^{d} s_{t}+z_{t+1}
\end{aligned}
$$

When young, each individual works to receive the wage rate. She allocates the income between consumption and saving as the deposit into the bank. When old, she receives the deposit interest rate $\left(R_{t+1}^{d}\right)$ on her savings and the income transfer $\left(z_{t+1}\right)$ from the government.

Let denote $\left(R_{t+1}^{l}, R_{t+1}^{l, w}\right)$ are the autarky and integration lending interest rate respectively. We assume that the government levies the tax rate $(\tau)$ on the domestic savings. Each individual only receives the after-tax rate of return paid by the bank. At autarky, the deposit interest rate $\left(R_{t+1}^{d}\right)$ is:

$$
R_{t+1}^{d}=(1-\tau) R_{t+1}^{l}
$$

Therefore, the taxation $(\tau)$ generates a gap between the lending and deposit rate. As a result, the consumption at an old age of one agent born at $t$ is:

$$
c_{t+1}^{o}=(1-\tau) R_{t+1}^{l} s_{t}+z_{t+1}
$$

By solving the utility maximization problem, the wedge enters the Euler equation, then, affects the saving rate $\left(s_{t}\right)$ by the young agent. The aggregate savings at time $t$ follows:

$$
S_{t}=N_{t} s_{t}=\frac{\beta}{1+\beta}\left(w_{t} N_{t}-\frac{N_{t} z_{t+1}}{\beta(1-\tau) R_{t+1}^{l}}\right)
$$

Similarly, replacing $\left(R_{t}^{l}\right)$ by $\left(R_{t}^{l, w}\right)$, the aggregate savings at integration follows:

$$
S_{t}=\frac{\beta}{1+\beta}\left(w_{t} N_{t}-\frac{N_{t} z_{t+1}}{\beta(1-\tau) R_{t+1}^{l, w}}\right)
$$

\subsubsection{Bank}

One representative bank collects savings to lend to firms. It covers the capital taxation $(\gamma)$ which accounts for one fraction of total revenue gained by lending to the firms.

$$
\Pi_{t}=R_{t} L_{t-1}^{B}-R_{t}^{l} D_{t-1}^{B}-\gamma R_{t} L_{t-1}^{B}
$$

The deposit market clearing condition requires the total demand of the deposit $\left(D_{t-1}^{B}\right)$ to be equal to the total supply of the saving by households $\left(S_{t-1}\right)$. The loans market clearing condition requires the total demand of the investment $\left(I_{t-1}\right)$ to be equal to the total supply of the fund by bank $\left(L_{t-1}^{B}\right)$. 


\section{Autarky economy}

At autarky, the inter-bank market clearing condition requires that the total supply of fund is equal to the total demand of deposit. Therefore, the aggregate saving supply is equal to the aggregate investment demand, giving the equilibrium lending rate.

$$
D_{t-1}^{B}=L_{t-1}^{B} \Leftrightarrow S_{t-1}=I_{t-1}
$$

The zero-profit condition implies that the capital taxation generates an investment wedge between the rental rate of capital and the lending rate.

$$
R_{t}=\frac{R_{t}^{l}}{(1-\gamma)}
$$

\section{Integration economy}

At financial integration, the representative bank in the Home economy can receive the deposits from foreign households and lend to domestic firms. One world lending interest rate, $\left(R_{t}^{l}=\right.$ $\left.R_{t}^{l, *}=R_{t}^{l, w}\right)$, clears the international inter-bank market, for which world aggregate investments are equal to world aggregate savings.

$$
S_{t-1}+S_{t-1}^{*}=I_{t-1}+I_{t-1}^{*}
$$

The zero profit condition for the Home representative bank still implies that the domestic rental rate of capital is related to the world lending interest rate by the investment wedge.

$$
R_{t}=\frac{R_{t}^{l, w}}{(1-\gamma)}
$$

Therefore, one country with a high investment wedge would suffer a high cost of capital, even the lending interest rate is equalized across countries.

\subsubsection{Government}

The government collects taxation and transfers tax revenue to the old agents. By assumption, the model focuses on distortion that the taxation generates on consumption and saving. At autarky, by using (4), the income transfer per each old agent follows:

$$
z_{t}=\frac{Z_{t}}{N_{t-1}}=\frac{\tau R_{t}^{l} N_{t-1} s_{t-1}+(\gamma /(1-\gamma)) R_{t}^{l} I_{t-1}}{N_{t-1}}
$$

whereby, the first and second term are revenues by taxing the savings and the investment respectively.

At integration, by using (5), the income transfer is related to the world lending interest rate:

$$
z_{t}=\frac{Z_{t}}{N_{t-1}}=\frac{\tau R_{t}^{l, w} N_{t-1} s_{t-1}+(\gamma /(1-\gamma)) R_{t}^{l, w} I_{t-1}}{N_{t-1}}
$$




\subsection{Equilibrium}

\subsubsection{Autarky equilibrium}

Plugging the income transfer (6) into the total saving supply (3) and taking into account the shares over output by labor income, $\left(w_{t} N_{t}=(1-\alpha) Y_{t}\right)$, and by capital income, $\left(R_{t+1} I_{t}=\alpha Y_{t+1}\right)$, we end up with the aggregate savings at equilibrium.

$$
S_{t}=\frac{(1-\alpha) Y_{t}-\left(\beta(1-\tau) R_{t+1}^{l}\right)^{-1} \gamma \alpha Y_{t+1}}{1+(\beta(1-\tau))^{-1}}
$$

Within the set-up with the income transfer by the government, the saving-output ratio $\left(S_{t} / Y_{t}\right)$ is decreasing on the saving wedge, given the output growth rate $\left(Y_{t+1} / Y_{t}\right)$. Therefore, one country with a lower saving wedge would have a higher saving rate. The demand for capital (2), taking into account the lending interest rate (4), is decreasing on the investment wedge since the latter affects the cost of capitals for firms. In the Home country, we have:

$$
\begin{aligned}
\frac{S_{t}}{Y_{t}} & =(1-\alpha) \vartheta-\frac{\alpha \mu}{R_{t+1}^{l}} \frac{Y_{t+1}}{Y_{t}} \\
\frac{K_{t}}{Y_{t}} & =\frac{\alpha(1-\gamma)}{R_{t}^{l}}
\end{aligned}
$$

whereby $\vartheta \equiv \frac{\beta(1-\tau)}{1+\beta(1-\tau)}$ and $\mu \equiv \frac{\gamma}{1+\beta(1-\tau)}$.

At the temporal equilibrium, the autarky interest rate is the solution for capital market clearing condition, $\left(S_{t-1}=K_{t}\right)$, which requires that the savings-output ratio (8) evaluated at time period $(t-1)$, multiplied by ratio $\left(Y_{t-1} / Y_{t}\right)$, equalizes the capital-output ratio $(9)$ at time period $(t)$.

$$
R_{t}^{l}=\frac{\alpha}{(1-\alpha)} \frac{Y_{t}}{Y_{t-1}} \frac{\mu+1-\gamma}{\vartheta}
$$

At the inter-temporal equilibrium, the capital at time period $(t+1)$ equalizes the savings at time period $(t): k\left(R_{t+1}^{l}, \gamma\right)=s\left(R_{t}^{l}, R_{t+1}^{l}, \tau, \gamma\right)$. Indeed, by replacing (4) into (2), then scaling the result by total effective unites of labor $\left(A_{t} N_{t}\right)$, we have:

$$
k\left(R_{t+1}^{l}, \gamma\right) \equiv \frac{K_{t+1}}{A_{t} N_{t}}=\left(\frac{\alpha(1-\gamma)}{R_{t+1}^{l}}\right)^{1 /(1-\alpha)}\left(1+g_{t+1}^{A}\right)\left(1+g_{t+1}^{N}\right)
$$

And by plugging (1) into (7), then scaling the result by $\left(A_{t} N_{t}\right)$, we have:

$s\left(R_{t}^{l}, R_{t+1}^{l}, \tau, \gamma\right) \equiv \frac{S_{t}}{A_{t} N_{t}}=\frac{(1-\alpha)(\alpha(1-\gamma))^{\alpha /(1-\alpha)} \beta(1-\tau)}{(1+\beta(1-\tau))\left(R_{t}^{l}\right)^{\alpha /(1-\alpha)}}-\frac{\gamma \alpha[\alpha(1-\gamma)]^{\alpha /(1-\alpha)}}{1+\beta(1-\tau)} \frac{\left(1+g_{t+1}^{A}\right)\left(1+g_{t+1}^{N}\right)}{\left(R_{t+1}^{l}\right)^{1 /(1-\alpha)}}$

The autarky steady state with perfect foresight is summarized on the following Theorem.

Theorem 2.2.1. There exists an unique and stable steady state for an autarky economy. At steady state, $\frac{\partial R^{l}}{\partial g}>0 ; \frac{\partial R^{l}}{\partial \tau}>0 ; \frac{\partial R^{l}}{\partial \gamma}<0 ;$ whereby $g \equiv\left(1+g^{A}\right)\left(1+g^{L}\right)-1$. 
Proof. Appendix

Both the productivity growth rate and the interest rate wedges can affect the equilibrium lending interest rate. A higher growth rate raises the demand for investment, which, in turn, raises the lending rate, given the saving supply. A higher saving wedge reduces the saving supply, which, in turn, raises the lending rate, given the investment demand. A higher investment wedge, however, reduces the investment demand and depresses the interest rate, given the saving supply. In brief, the interaction of growth and wedges can generate various patterns of autarky interest rate: one country with a high productivity growth rate does not necessarily have a high interest rate if it also has a low saving wedge and/or a high investment wedge.

\subsubsection{Integration Equilibrium}

At integration, capital is free mobile, then the lending interest rate is equalized across countries. Since the wedges are country-specific, the deposit interest rate and the rental rate of capital are different across countries. Therefore, both savings and investment are different across countries.

At integration temporal equilibrium, the world capital market clearing condition, $\left(K_{t}+K_{t}^{*}=S_{t-1}+\right.$ $\left.S_{t-1}^{*}\right)$, gives the world lending interest rate.

$$
R_{t}^{l, w}=\frac{\alpha}{(1-\alpha)} \frac{Y_{t}^{w}}{Y_{t-1}^{w}} \frac{\bar{\mu}+1-\bar{\gamma}}{\bar{\vartheta}}
$$

whereby, $\bar{\mu} \equiv \frac{Y_{t}}{Y_{t}^{w}} \mu+\frac{Y_{t}^{*}}{Y_{t}^{w}} \mu^{*} ; \bar{\gamma} \equiv \frac{Y_{t}}{Y_{t}^{w}} \gamma+\frac{Y_{t}^{*}}{Y_{t}^{w}} \gamma^{*} ; \bar{\vartheta} \equiv \frac{Y_{t-1}}{Y_{t-1}^{w}} \vartheta+\frac{Y_{t-1}^{*}}{Y_{t-1}^{w}} \vartheta^{*} ; Y_{t}^{w} \equiv Y_{t}+Y_{t}^{*} ; Y_{t-1}^{w} \equiv Y_{t-1}+Y_{t-1}^{*}$.

At integration inter-temporal equilibrium, the world demand of capital for time period $(t+1)$ is equal to the world supply of savings at time period $(t)$, which are obtained by aggregating $(11)$ and $(12)$ over all countries, respectively.

Theorem 2.2.2. There exists a unique, stable steady state for an integration world economy, and the world interest rate, given by equation 13 , satisfies: $\min \left(R_{t}^{l}, R_{t}^{l, *}\right)<R_{t}^{l, w}<\max \left(R_{t}^{l}, R_{t}^{l, *}\right)$.

Proof. Appendix

As the world rate lies between the lowest and the highest autarky rates, the capital flows out of the country with low autarky rate into the country with high autarky rate until the interest rate is equalized across countries. We apply the principle to analyze the pattern of international capital flows on the next section.

\section{International Capital Flows}

Let denote $B_{t+1}$ as the stock of net foreign assets at the end of period $t$ in the Home country. According to Obstfeld and Rogoff (1996), the savings by the young agents is allocated between the net foreign assets and the domestic capital stock: $S_{t}=B_{t+1}+K_{t+1}$. At steady state, the saving-output (8) and capital-output ratios (9) are constant. Therefore, the ratio of net foreign assets over output is also constant.

$$
\overline{\bar{Y}}=\overline{\bar{S}} \frac{1}{(1+g)}-\frac{\bar{K}}{Y}=\frac{(1-\alpha) \vartheta}{(1+g)}-\frac{\alpha}{R^{l, w}}(\mu+1-\gamma)
$$


The Home autarky interest rate 100 and corresponding net foreign assets at steady state are:

$$
\begin{aligned}
& R^{l}=\frac{\alpha(1+g)}{(1-\alpha)} \frac{(\mu+1-\gamma)}{\vartheta} \\
& \overline{\bar{B}}=\alpha(\mu+1-\gamma) \frac{\left(R^{l, w}-R^{l}\right)}{R^{l, w} R^{l}}
\end{aligned}
$$

Let denote $C A_{t}$ as the Home current account at period $t$, which is the change of net foreign assets between $(t+1)$ and $t: C A_{t}=B_{t+1}-B_{t}$. Therefore,

$$
\frac{C A_{t}}{Y_{t}}=\frac{B_{t+1}}{Y_{t+1}} \frac{Y_{t+1}}{Y_{t}}-\frac{B_{t}}{Y_{t}}
$$

The net total capital inflows are measured as the negative value of the current account, which is one constant fraction of net foreign assets-output ratio at steady state. By using (15), we have:

$$
-\frac{\overline{C A}}{Y}=g\left(-\frac{\bar{B}}{Y}\right)=g \alpha(\mu+1-\gamma) \frac{\left(R^{l}-R^{l, w}\right)}{R^{l, w} R^{l}}
$$

Therefore, we end up with one classical result that one economy receives the capital inflows only if its interest rate is higher at autarky than at world integration.

$$
-\frac{\overline{C A}}{Y}>0 \Leftrightarrow R^{l}>R^{l, w}
$$

Our central analysis is on the dependence pattern of net total capital inflows on the productivity growth, which is given by the value of the following formula:

$$
\frac{\partial(-C A / Y)}{\partial g}
$$

By $(13)$, the steady-state world interest rate depends on the world average growth rate and wedges.

$$
R^{l, w}=\frac{\alpha}{(1-\alpha)}(1+\bar{g}) \frac{\bar{\mu}+1-\bar{\gamma}}{\bar{\vartheta}}
$$

whereby, the world average growth rate: $(1+\bar{g})=\frac{Y_{t-1}}{Y_{t-1}^{w}}(1+g)+\frac{Y_{t-1}^{*}}{Y_{t-1}^{w}}\left(1+g^{*}\right)$.

Replacing 14. 17) into (16), the Home net total capital inflows at steady state are as below:

$$
-\frac{\overline{C A}}{Y}=(1-\alpha)(\mu+1-\gamma)\left(\frac{g}{(1+\bar{g})} \frac{\bar{\vartheta}}{(\bar{\mu}+1-\bar{\gamma})}-\frac{g}{(1+g)} \frac{\vartheta}{(\mu+1-\gamma)}\right)
$$

The closed-form solution for net total capital inflows allows the investigation on the roles of productivity growth and wedges on shaping the pattern of international capital flows. We examine cases with different combinations of growth and wedges by calibration on one sample of about 180 economies. In the next step, we describe the calibration method and data sample.

\section{Data Description}

Each variable is computed by each year and then, averaged over time period 1980-2013. The yearly net total capital inflows $\left(n e g C A 2 y_{t}\right)$ is measured as the negative current account per output ratio on percentage, which is from the updated and extended version of the dataset of net private and public capital flows constructed by Alfaro, Kalemli-Ozcan and Volosovych (2014). The panel includes a large 
number of countries, including both developing and advanced economies, from 1980 to 2013.

The yearly productivity net growth rate $\left(G D P\right.$ pcgrowt $\left.h_{t}\right)$ is measured by the output-per-capita net growth rate. Based on Penn World Table 8.1 (2015), we compute the output per capita as the real output at constant 2005 national price (in USD) divided by the total population, explored from World Development Indicators. According to the Neo-Classical growth model (Solow (1956), Swan (1956)), the long-run growth rate of output-per-capita is equal to the productivity growth rate.

The saving wedge $\left(t a u_{t}\right)$ at each year $(t)$ is computed by the yearly nominal deposit interest rate $\left(R_{t}^{d}\right)$ and yearly nominal lending interest rate $\left(R_{t}^{l}\right)$, which are from World Development Indicators from 1980 to 2013. For individual countries, we keep only the country with the average saving wedge which has a value consistent with definition used in our model, $(0<$ atau $<1)$.

$$
\operatorname{tau}_{t}=\frac{R_{t}^{l}-R_{t}^{d}}{R_{t}^{l}}
$$

For the yearly investment wedge $\left(\right.$ gamma $\left._{t}\right)$, we estimate the marginal product of capital $\left(P M P K L_{t}\right)$, by the method proposed by Caselli and Feyrer (2007). This method accounts for the share of producible capitals on the total income, denoted by $\left(\alpha_{k}\right)$, and the difference between the price of output $\left(p l_{g d p o}\right)$ and price of capital stock $\left(p l_{k}\right)$. The data about the output-side real GDP (cgdpo) and capital stock $(c k)$ (all at current purchasing power parity (PPPs) in million 2005 USD) and their associated prices are from Penn World Table 8.1 (2015). Since the marginal product of capital is a real value, we use the real lending interest rate $\left(R_{t}^{l, r}\right)$ to compute the investment wedge and only keep the observations with $(0<$ agamma $<1)$.

$$
P M P K L_{t}=\alpha_{k} \cdot \frac{p l_{g d p o, t} \cdot c g d p o_{t}}{p l_{k, t} \cdot c k_{t}} \Rightarrow g a m m a_{t}=\frac{P M P K L_{t}-R_{t}^{l, r}}{P M P K L_{t}}
$$

Table 3.0.1: DESCRIPTIVE STATISTICS

\begin{tabular}{lccccc}
\hline \hline Variables & Obs & Mean & Std. Dev. & Min & Max \\
\hline \hline Net total capital inflows (anegCA2y) (\%) & 179 & 4.915729 & 7.569045 & -13.81684 & 38.93217 \\
Output-per-capita growth rate (aGDPpcgrowth) $(\%)$ & 160 & 1.881766 & 1.852483 & -1.409037 & 10.20622 \\
Saving wedge (atau) & 52 & 0.4272648 & 0.1271043 & 0.1510625 & 0.6848503 \\
Investment wedge (agamma) & 52 & 0.449014 & 0.2285341 & 0.0229384 & 0.9861003 \\
\hline
\end{tabular}

Table 3.0.1 reports the descriptive statistics on one cross-section data sample of 180 countries. The net total capital inflows have a mean of (4.9)\% with a standard deviation equal to (7.57). The output-percapita growth rate has a lower mean of $(1.88 \%)$ with a lower standard deviation of $(1.85 \%)$. The saving wedge has a mean (0.42) with a standard deviation of (0.13) while the investment wedge has a higher mean $(-0.44)$ but with a higher standard deviation $(0.22)$. In brief, the data set offers rich variation for exploring the empirical and simulation evidence about the pattern of international capital flows.

\section{Calibration Cases}

We simulate the pattern of capital flows at the integration steady state. The initial net total capital inflows in Home and Foreign economy can be different to zero. We allow the productivity growth and wedges to change at Home but stay constant at Foreign economy. By focusing on the Home economy, 
each combination of growth rate and wedge can be considered as within one country. Using that strategy, the calibration can show the dependence pattern of capital flows on growth across countries.

For the choice of parameters, we make reference to the descriptive statistics presented on Table (3.0.1). In detail, the saving wedge is on the range of $(0.15,0.68)$, which includes the minimum and maximum values of wedge on data. The value of investment wedge is similar, within the range of $(0.2,0.98)$ which is the same as the data. For the productivity growth rate, we take the maximum value revealed by data, and the minimum at $1 \%$ to rule out the case of negative growth rate. As shown in Table (3.0.2), the values of parameters are consistent to the data.

Table 3.0.2: Parameters for Calibration

\begin{tabular}{|c|c|c|}
\hline Parameters & Home Economy & Foreign Economy \\
\hline \multicolumn{3}{|c|}{ Case 1: Symmetric Growth Rates and Asymmetric Wedges } \\
\hline Productivity Growth Rate & $g \in(0.01,0.10)$ & $g^{*} \in(0.01,0.10)$ \\
\hline \multicolumn{3}{|c|}{ Case 1.1: Asymmetric Saving Wedge } \\
\hline Saving Wedge & $\tau \in(0.15,0.68)$ & $\tau^{*}=0.1$ \\
\hline Investment Wedge & $\gamma=0.1$ & $\gamma^{*}=0.1$ \\
\hline \multicolumn{3}{|c|}{ Case 1.2: Asymmetric Investment Wedge } \\
\hline Saving Wedge & $\tau=0.1$ & $\tau^{*}=0.1$ \\
\hline Investment Wedge & $\gamma \in(0.02,0.98)$ & $\gamma^{*}=0.1$ \\
\hline \multicolumn{3}{|c|}{ Case 2: Asymmetric Growth Rates and Asymmetric Wedges } \\
\hline Productivity Growth Rate & $g \in(0.01,0.10)$ & $g^{*}=0.01$ \\
\hline Saving Wedge & $\tau \in(0.15,0.68)$ & $\tau^{*}=0.68$ \\
\hline Investment Wedge & $\gamma \in(0.02,0.98)$ & $\gamma^{*}=0.1$ \\
\hline
\end{tabular}

Table 3.0.2 shows parameters of models for four different calibration cases. Case 1 employs symmetric growth rates and asymmetric wedges to analyze the role of wedges on determining the pattern of capital flows. In detail, the growth rate raising from (1\%) to (10\%) at both Home and Foreign. The Home saving wedge increases, given constant Foreign wedge on case 1.1, while the Home investment wedge goes up, given constant Foreign one on case 1.2.

The focal analysis is on case 2 featured by asymmetric growth and asymmetric wedges. The rich combination of parameters characterizes the complicated dependence of capital flows on growth. The Home growth rate surges from (1\%) to (10\%), given constant Foreign one at (1\%). Moreover, the saving wedge is initially lower at Home than at Foreign but tends to approach the foreign level, and the Home investment wedge is initially lower, but follows one increasing path to be higher than the Foreign one.

\subsection{Linear Pattern with Symmetric Growth and Asymmetric Wedges}

With symmetric growth rates and asymmetric wedges across countries, $\left(g=g^{*}, \tau \neq \tau^{*} ; \gamma \neq \gamma^{*}\right)$, the Home steady state net total capital inflows (18) are rewritten as:

$$
-\frac{\overline{C A}}{Y}=(1-\alpha)(\mu+1-\gamma) \frac{g}{(1+g)}\left(\frac{\bar{\vartheta}}{\bar{\mu}+1-\bar{\gamma}}-\frac{\vartheta}{\mu+1-\gamma}\right)>0 \Leftrightarrow \frac{\vartheta}{\mu+1-\gamma}<\frac{\bar{\vartheta}}{\bar{\mu}+1-\bar{\gamma}}
$$

Therefore, domestic wedges determine whether one economy receives capital inflows. Domestic wedges also alleviates the impact of growth on the capital inflows by following proposition. 
Proposition 3.1.1. At integration steady state with symmetric growth rates, the pattern of international capital flows depends on the domestic interest rate wedges:

$$
\frac{\partial(-\overline{C A / Y})}{\partial g}>0 \Leftrightarrow \frac{\vartheta}{\mu+1-\gamma}<\frac{\bar{\vartheta}}{\bar{\mu}+1-\bar{\gamma}}
$$

Proof. The result is attained by setting the derivative of $(-C A / Y)$ w.r.t the growth to be positive.

$$
\frac{\partial(-\overline{C A / Y})}{\partial g}=\frac{(1-\alpha)}{(1+g)^{2}}\left(\frac{\mu+1-\gamma}{\bar{\mu}+1-\bar{\gamma}} \bar{\vartheta}-\vartheta\right)
$$

Proposition (3.1.1) stresses the role of wedges on setting the pattern of capital flows. The capital inflows are increasing on growth if the inequality (20) on wedges is satisfied. Otherwise, they are decreasing on growth. As a result, the proposition implies the linear dependence pattern of capital inflows on productivity growth. A higher growth can either raise or reduce the inflows of capital. The wedges define the pattern of international capital flows on case of symmetric growth rates.

Figure 3.1.1: Linear Pattern of International Capital Flows: Calibration
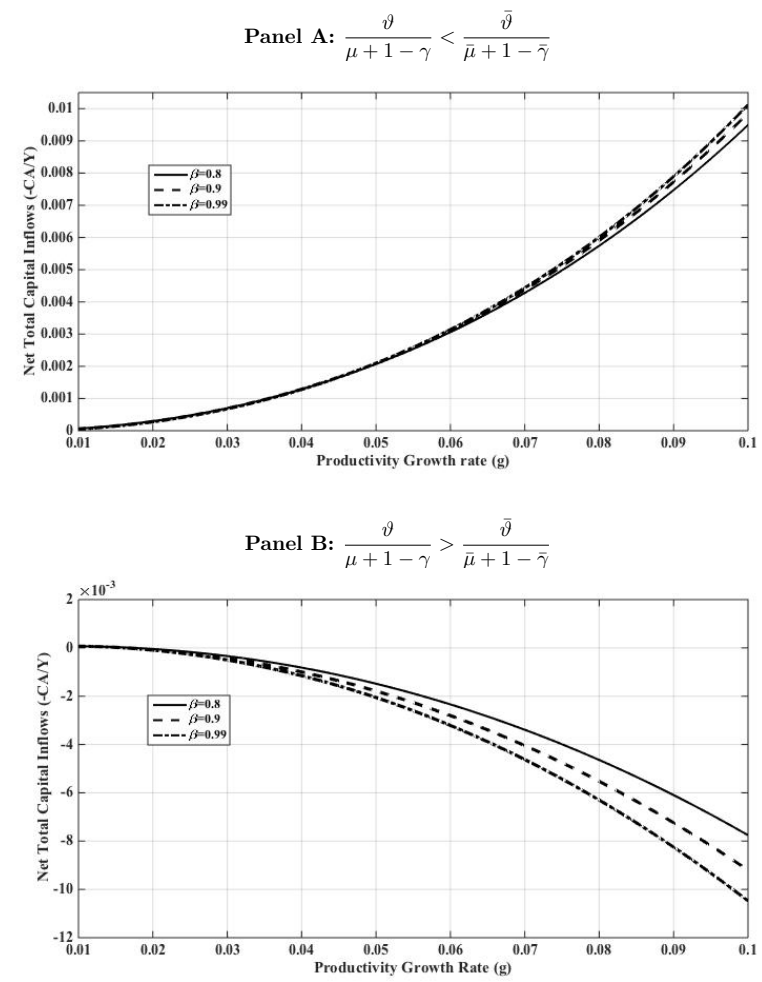

\footnotetext{
Notes: Panel A with asymmetric saving wedge: $\tau \in(0.15,0.68) ; \tau^{*}=\gamma=\gamma^{*}=0.1$. Panel B with asymmetric investment wedge: $\gamma \in(0.02,0.98) ; \tau=\tau^{*}=\gamma^{*}=0.1$. Their common parameters are symmetric growth $g=g^{*} \in(0.01,0.10)$, capital income share of output $(\alpha=0.33)$; Home output share of world output $(\lambda=0.3)$; and time discount rate $(\beta=(0.8,0.9,0.99))$.
}

The intuition behind the linearity of the pattern of international capital flows relies on the impact of wedges on interest rate. The domestic interest rate is increasing on the saving wedge and decreasing on 
the investment wedge. Therefore, given the symmetric growth across countries, the difference between domestic and world average wedges bridges the gap between the domestic and world interest rate. The gap, in turn, underlines the misalignment between domestic investment and savings. If the condition

20. satisfies, the investment surpasses the savings and the economy receives the foreign capital inflows. Otherwise, the investment falls below the savings and there are inflows of capital. These indicate that within the symmetric growth, the asymmetric wedges monitors the impact of growth on net total capital inflows.

Figure (3.2.1) illustrates the calibration results with symmetric growth and asymmetric wedges across countries. On Panel A, the net total capital inflows are increasing on productivity growth. By Proposition 3.1.1, the growth exerts positive impact on capital inflows since domestic saving and investment wedges satisfy the condition 20. However, on Panel B, when the values of wedges do not satisfy the condition (20), the capital inflows are decreasing on growth. The patterns of capital flows are similar for different values of time discount rate $(\beta)$ on two panels. The calibration results therefore support the theoretical role of wedges on shaping the pattern of international capital flows.

The theory, supported by the results of calibration, offers an explanation for the controversy between the allocation puzzle and Neo-Classical growth model. For the economies in which the inequality (20) does not hold, the allocation puzzle emerges as a higher growth rate results in the reduction of net total capital inflows. The prediction of Neo-Classical growth model, however, can be applied if the inequality 20 holds. As a consequence, a higher productivity growth rate raises the inflows of net total capital. Our proposed model uncovers the mechanism to align the allocation puzzle with the prediction by NeoClassical growth model.

Proposition 3.1.1), however, has one shortcoming. Its implication on the linear pattern of capital flows can only explain one of two observed patterns: the net total capital inflows are either decreasing or increasing on growth. Therefore, the proposition is silent on the question whether the capital flows can be decreasing then increasing on growth. This motivates the use of heterogeneous growth rates to further explore the pattern of capital flows, which is presented in the next subsection.

\subsection{Non-Linear Pattern with Asymmetric Growth and Asymmetric Wedges}

Within the framework with asymmetric growth and asymmetric wedges across countries $\left(g \neq g^{*} ; \tau \neq\right.$ $\left.\tau^{*} ; \gamma \neq \gamma^{*}\right)$, the net total capital inflows are affected by both productivity growth and wedges. Indeed, by (18), one economy can receive the inflows of capital if the domestic growth is high enough:

$$
-\frac{C A}{Y}>0 \Leftrightarrow g>(1+\bar{g}) \frac{\vartheta}{\bar{\vartheta}} \frac{\bar{\mu}+1-\bar{\gamma}}{\mu+1-\gamma}-1
$$

The condition for positive capital inflows captures the interaction of growth and wedges. The first term $(1+\bar{g})$ illustrates the classical implication by Neo-Classical growth model that one economy growing faster than the rest of world would receive the inflows of capital. The second term, $\vartheta(\bar{\mu}+1-\bar{\gamma}) / \bar{\vartheta}(\mu+1-\gamma)$, accounts for the role of wedges. In detail, by setting $(1+g)=(1+\bar{g})$, the condition turns out to be the same condition for positive inflows of capital on the case of linear pattern, $\vartheta /(\mu+1-\gamma)<\bar{\vartheta} /(\bar{\mu}+1-\bar{\gamma})$. The capital inflows depend on both growth and wedges.

Our focal point is on impact of growth on capital inflows, which is given by following Proposition. 
Proposition 3.2.1. At integration steady state with asymmetric growth rates, the pattern of international capital flows for one economy is increasing only if its growth rate is high enough (i.e, passing over one threshold, denoted as $H(\bar{g}, \tau, \gamma))$ :

$$
\frac{\partial(-\overline{C A / Y})}{\partial g}>0 \Leftrightarrow g>H(\bar{g}, \tau, \gamma)
$$

whereby, $H(\bar{g}, \tau, \gamma) \equiv(1+\bar{g})\left(\frac{\vartheta / \bar{\vartheta}}{\left(1+\lambda^{*} g^{*}\right)} \frac{(\bar{\mu}+1-\bar{\gamma})}{(\mu+1-\gamma)}\right)^{1 / 2}-1$

Proof. The proof is provided by setting the condition that $\partial(-\overline{C A / Y}) / \partial g>0$.

$$
\frac{\partial(-\overline{C A / Y)}}{\partial g}=(1-\alpha)\left(\frac{\left(1+\lambda^{*} g^{*}\right)(\mu+1-\gamma)}{(\bar{\mu}+1-\bar{\gamma})} \frac{\bar{\vartheta}}{(1+\bar{g})^{2}}-\frac{\vartheta}{(1+g)^{2}}\right)
$$

Our model proposes one non-linear pattern of international capital flows: the impact of productivity growth on net total capital inflows depends on the value of growth rate. There is one critical threshold of productivity growth rate, which changes the pattern of capital inflows. If one country's growth rate passes the threshold, its net total capital inflows raise for an improvement of productivity growth. If one country's growth rate stays below the threshold, the increase of productivity growth results in a reduction of net total capital inflows. The existence of the threshold breaks the linear dependence pattern of net total capital inflows on productivity growth.

The intuition behind the non-linearity on pattern of international capital flows relies on the interaction of growth and wedges on generating the misalignment between domestic and world interest rate. For asymmetric growth and wedges across countries, both the productivity growth and wedges jointly affect the interest rate. For an increase of productivity growth, the domestic interest rate can raise or fall, depending on the relative impact of growth against that of wedges. By equation (16), the difference between domestic and world interest rate, in turn, creates the gap between domestic investment and savings. Therefore, the combination of asymmetric growth and wedges implies that investment-savings gap can widen or shrink, depending on the value of productivity growth. Only if the growth rate is high enough, the role of growth wins that of wedges, and the gap widens so that there are inflows of capital. In short, the interaction of asymmetric growth and wedges can make the inflows of capital to be decreasing then increasing on the productivity growth.

Another interpretation of a non-linear pattern of capital flows is underlined by the relationship between productivity growth and net foreign assets. By equation (16) and (21) one economy with low growth rate is a net creditor with positive net foreign assets $(B / Y>0)$ while one economy with high growth rate is a net debtor with negative net foreign assets $(B / Y<0)$. Furthermore, since $C A / Y=g(B / Y)$, the net creditor runs a surplus current account or outflows of capital, and the net debtor experiences a deficit current account or inflows of capital. Therefore, a higher growth rate can result in either less inflows of capital or more inflows of capital, depending on the net international investment position: $\partial(-C A / Y) / \partial g=\partial(-B / Y)$. For economies with low growth rate, $(-B / Y)$ is negative; then, an increase of growth reduces the capital inflows. For economies with high growth rate, $(-B / Y)$ is positive; then, a higher growth raises the capital inflows. As a result, the inflows of capital are decreasing on growth for slow-growing economies but increasing on growth for fast-growing counterparts. These suggest that 
the net foreign assets position serves as one channel through which the productivity growth exerts the non-linear impact on the capital flows.

\subsubsection{Calibration Results}

Figure (3.2.1) presents the calibration exercise for the case of asymmetric growth and asymmetric wedges across countries. By revealing one U-shaped pattern of international capital flows for different values of time discount rate $(\beta)$, the calibration results are consistent to the theoretical implication. For $(\beta=0.8)$, over the range of $(1 \%, 6 \%)$, an increase of growth reduces the inflows of capital. Over the range of $(6 \%, 10 \%)$, a higher growth rate raises the capital inflows. Proposition (3.2.1) suggests that the value of country-specific threshold is $6 \%$; this value is denoted by $H(\bar{g}, \tau, \gamma)$, which can deviate from average growth rate by one term capturing the wedges. Therefore, the net total capital inflows changes when passing the threshold. The calibration results postulate that the impact of productivity growth on net total capital inflows follows one quadratic function.

Figure 3.2.1: Non-Linear Pattern of International Capital Flows: Calibration

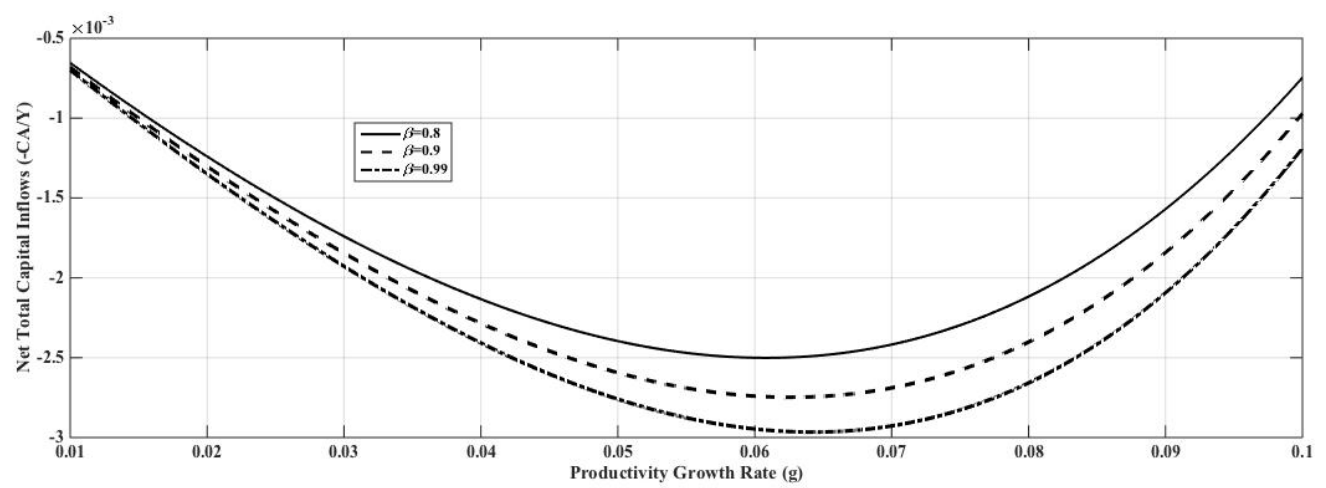

Notes: Asymmetric growth: $g \in(0.01,0.10) ; g^{*}=0.01$. Asymmetric saving wedge: $\tau \in(0.15,0.68) ; \tau^{*}=0.68$. Asymmetric investment wedge: $\gamma \in(0.022,0.98) ; \gamma^{*}=0.1$. Other parameters: capital income share of output $(\alpha=0.33)$; Home and Foreign output $\left(y=y^{*}=100\right)$; time discount rate $(\beta=(0.8,0.9,0.99))$.

The calibration results reveal the difference between the non-linear and linear pattern of international capital flows. The non-linear curve has one smoothed transition from the decreasing to increasing path when the productivity growth rate passes the threshold. However, the linear curve, as seen in Figure (3.2.1), can imply one structural break between these two paths. The difference can be underlined by the value of threshold. The threshold on the non-linear pattern, given by (22), is applied for growth rate since both growth and wedges determine the interest rates. For the linear pattern, the condition given by 20 only relies on the wedges. Therefore, the dependence of capital flows on growth can be one function of growth only on the non-linear case with asymmetric growth and wedges. In brief, the interaction between growth and wedges formulates a U-shaped pattern of capital flows.

\subsubsection{Empirical Evidences}

We carry out the empirical analysis for one sample of about 180 economies, covering both advanced and developing economies. The strategy is to make the regressions on both the full sample and two smaller 
sub-samples. Proposition 3.2.1 suggests that the turning point can be approximated by the averaged value of productivity growth rate at $(1.8 \%)$. Therefore, the first sub-sample covers the observations with productivity growth rate being smaller than $(1.8 \%)$ while the second one gathers the rest of observations. If the net total capital inflows are decreasing on the first sub-sample and increasing on the second one, the existence of a non-linear pattern of international capital flows can be confirmed.

Table (3.2.1) shows the regression results of net total capital inflows on the productivity growth rate. In column 1, the coefficient of productivity growth rate is insignificant for the linear term. However, the results in column 2 demonstrate that the productivity growth rate has a significant impact on the net total capital inflows only when we consider one quadratic function. The effect of productivity growth on international capital inflows depends on the value of growth: $\partial($ anegCA2y) $/ \partial(a G D P p c g r o w t h)=$ 0.54.aGDPpcgrowth - 1.6. These indicate that the pattern of capital flows can follow a U-shaped curve.

The regressions on the two sub-samples are presented on last two columns. In column 3, the net total capital inflows are decreasing on the productivity growth rate for the first sub-sample while, as can be seen in column 4, they are increasing on the growth for the second one. The results found in these two columns verify one U-shaped curve on the pattern of capital flows recorded in the first two columns. Moreover, since the coefficient of growth has a higher absolute value in column 3 than that in column 4 , the impact of growth on the capital inflows is stronger on the first sub-sample than on the second one. The regression results therefore lay a valid ground for a non-linear pattern of international capital flows.

Table 3.2.1: Cross-section regression of long-run net total capital inflows on productivity growth rate: full sample (col.1 \& 2) and two sub-samples (col.3 \& 4).

\begin{tabular}{|c|c|c|c|c|}
\hline VARIABLES & $\begin{array}{l}\text { (1) } \\
\text { anegCA2y }\end{array}$ & $\begin{array}{l}(2) \\
\text { anegCA2y }\end{array}$ & $\begin{array}{l}(3) \\
\text { anegCA2y }\end{array}$ & $\begin{array}{l}(4) \\
\text { anegCA2y }\end{array}$ \\
\hline $\begin{array}{l}\text { Productivity Growth Rate } \\
\text { (aGDPpcgrowth) }\end{array}$ & $\begin{array}{l}0.0662 \\
(0.314)\end{array}$ & $\begin{array}{l}-1.598^{* * *} \\
(0.584)\end{array}$ & $\begin{array}{l}-1.639^{*} \\
(0.931)\end{array}$ & $\begin{array}{l}1.197^{* *} \\
(0.473)\end{array}$ \\
\hline $\begin{array}{l}\text { Squared value of (aGDPpcgrowth) } \\
\text { (aGDPpcgrowth } 2)\end{array}$ & & $\begin{array}{l}0.269^{* * *} \\
(0.0806)\end{array}$ & & \\
\hline Constant & $\begin{array}{l}4.480^{* * *} \\
(0.832)\end{array}$ & $\begin{array}{l}5.734^{* * *} \\
(0.890)\end{array}$ & $\begin{array}{l}6.049^{* * * *} \\
(0.997)\end{array}$ & $\begin{array}{l}0.265 \\
(1.696)\end{array}$ \\
\hline $\begin{array}{l}\text { Observations } \\
\text { R-squared }\end{array}$ & $\begin{array}{l}158 \\
0.000\end{array}$ & $\begin{array}{l}158 \\
0.067\end{array}$ & $\begin{array}{l}79 \\
0.039\end{array}$ & $\begin{array}{l}79 \\
0.077\end{array}$ \\
\hline $\begin{array}{l}\text { Notes: standard errors in parenth } \\
\text { of current account-output ratios (9) } \\
\text { capita growth rates. Data on the } \\
\text { Volosovych 2014); the productivit } \\
\text { constant } 2005 \text { national prices from } \\
\text { on percentage. The sub-sample in c } \\
\text { smaller than world average growth } \\
\text { column (4). See descriptive statistic }\end{array}$ & $\begin{array}{l}\text { ses. }{ }^{* * *} \mathrm{p} \\
\text { over } 1980 \text { - } \\
\text { t total capit } \\
\text { growth rate } \\
\text { enn World } \mathrm{T} \\
\text { lumn (3) inc } \\
\text { ate (1.8\%). } \\
\text { for more de }\end{array}$ & $\begin{array}{l}\text { ** } \mathrm{p}<0.05 \\
(a G D P p c g \\
\text { flows (anegC } \\
\text { leasured by } \\
\text { 8.1. Variabl } \\
\text { sthe observa } \\
\text { rest of obse }\end{array}$ & $\begin{array}{l}<0.1 \text {. (ane } \\
\text { i) is the ave } \\
\text { is from Alf: } \\
\text { er capita val } \\
\text { e the average } \\
\text { with product } \\
\text { on is include }\end{array}$ & $\begin{array}{l}2 y) \text { is the average } \\
\text { of the output-per- } \\
\text { Kalemli-Ozcan and } \\
\text { the real output at } \\
\text { les over 1980-2013, } \\
\text { growth rate being } \\
\text { the sub-sample in }\end{array}$ \\
\hline
\end{tabular}

Figure (3.2.2) illustrates the empirical evidences on U-shaped pattern of capital flows. On Panel A, the net total capital inflows are decreasing and then increasing on growth for the full sample. On Panel $\mathrm{B}$, for countries with lower domestic productivity growth rate than world average one, such as United States $(1.67 \%)$ and Japan $(1.79 \%)$, the net total capital inflows are decreasing on growth. However, on Panel C, for countries with higher domestic growth rate than world average one, such as China (8.95\%) and Republic of Korea (5.82\%), the inflows of capital are increasing on growth. In other words, these countries can gain more inflows of capital for an increase of productivity growth rate. To conclude, the pattern of capital flows revealed by data is consistent with the theory. 
Figure 3.2.2: Non-Linear Pattern of International Capital Flows: Data

Panel A: Net total capital inflows and Productivity growth rate: quadratic pattern.

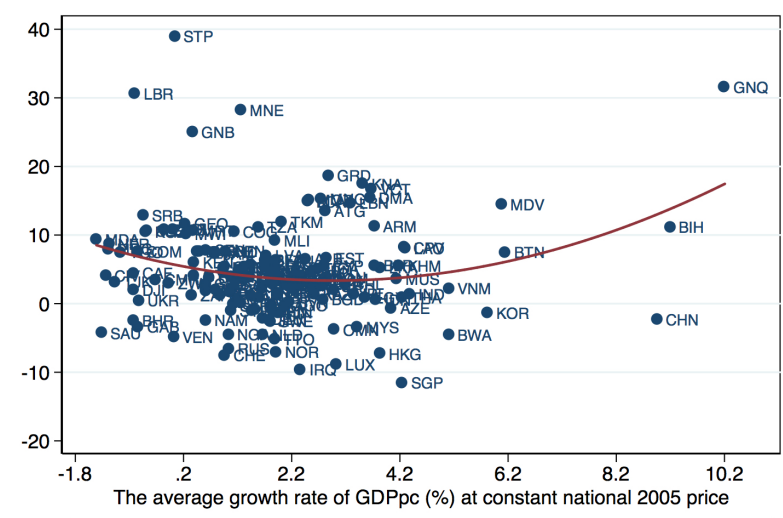

- The average net total capital inflows per GDP (\%) — Fitted values

Panel B: Net total capital inflows and Productivity growth rate: decreasing path.

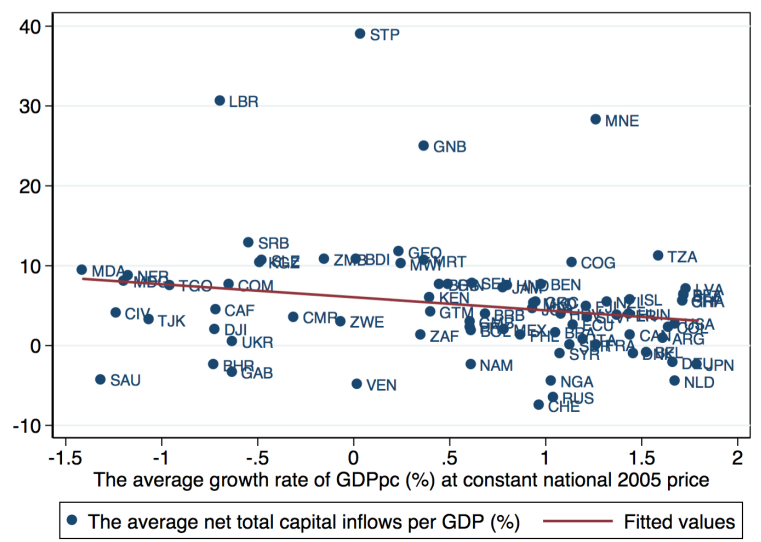

Panel C: Net total capital inflows and Productivity growth rate: increasing path.

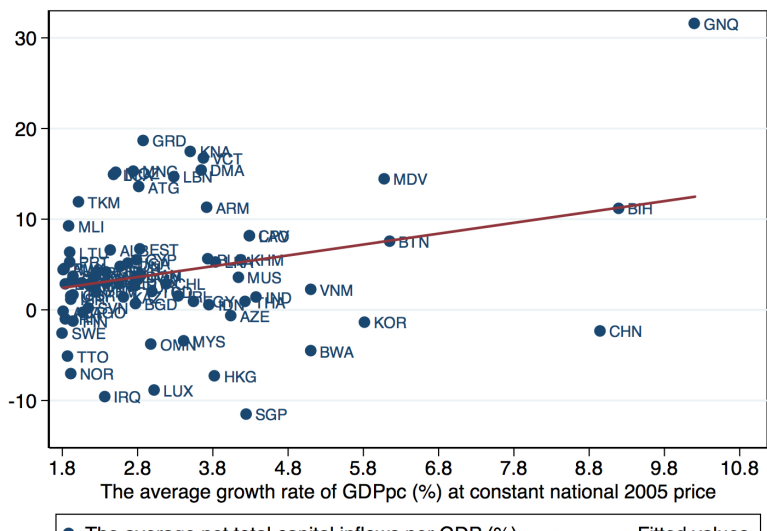

- The average net total capital inflows per GDP $(\%) \quad$ Fitted values

Notes: The net total capital inflows is average of the current account-output ratios over 1980-2013. The productivity growth rate is the average of output-per-capita growth rates over 1980-2013. Data about the net total capital inflows is from Alfaro, Kalemli-Ozcan and Volosovych (2014); the outputper-capita growth rate is the per capita value of the real output at constant 2005 national prices from Penn World Table 8.1. Variables are the average value over 1980-2013, on percentage. 


\subsubsection{Literature Discussion}

By employing the interaction of economic growth and interest rate wedges, we show that international capital flows follow a non-linear pattern rather than a linear pattern as proposed by previous literature. Following this pattern, the net total capital inflows are decreasing on productivity growth for low growth rates, then increasing for high growth rates. This suggests that the implication of the Neo-Classical growth model only covers the economies with high growth rates. Furthermore, the non-linearity of the capital flows pattern implies that, by controlling for the wedges, the net total capital inflows depend only on the productivity growth. Therefore, one economy could receive more inflows of capital for an improvement of productivity growth rate if its growth rate is high enough.

The U-shaped pattern of capital flows, proposed in this paper, can shed a light on recent controversies about cross-border capital flows. The Lucas paradox (Lucas (1990)) states that the capital does not flow from rich to poor economies which have higher marginal product of capital due to scare capital stocks. With symmetric growth and asymmetric wedges across countries, the wedges determine the direction of capital inflows. One economy can only receive the inflows of capital only if its domestic wedges satisfies the inequality (19). Therefore, one rich country can receive the capital inflows if 190 holds, and one poor country can have the outflows of capital if 190 fails.

The paper also provides an explanation for the up-hill capital flows (Prasad, Rajan, and Subramanian 【(2007)) that the capital flows from developing to advanced economies. By condition 21], one developing economy with high growth rate and scarcity of capital can export capital to the rest of world if its domestic growth is below the required threshold. One advanced economy with low growth rate and abundance of capital still receives the capital if its growth is just enough to pass the threshold.

Finally, the framework presented here implies that the allocation puzzle Gourinchas and Jeanne (2013)), which records that one fast growing economy tends to make foreign investment, can be extended from the Non-OECD to OECD economies. If satisfying the condition 22 for the non-linear pattern of capital flows, the decreasing pattern of capital flows applies for the economies whose growth rate is lower than the threshold. Therefore, even one industrial economy with too low growth rate (being lower than threshold) can also fall into the region of allocation puzzle. In summary, the paper describes a flexible model which can capture the pattern of capital flows for both rich and poor economies as well as both developing and advanced economies.

\section{Conclusion}

The paper provides an original insight into the non-linear dependence pattern of international capital flows on productivity growth. We construct one unified model to account for two contrasted patterns of capital flows: decreasing (allocation puzzle) or increasing (Neo-Classical growth model). The model places an emphasis on the interaction of growth and interest rate wedges on determining the capital flows. The framework can also account for the pattern of capital flows in both advanced and developing economies. In conclusion, the paper sheds a new light on the key determinants of international capital flows, including asymmetric growth and wedges across countries.

The paper carries policy implications. As the threshold of economic growth mentioned on Proposition

3.2.1 is country-specific and decreasing on the saving wedge but increasing on the investment wedge, 
the policy directed to increase the growth needs to be equipped with the policies which raise the saving wedge or reduce the investment wedge. The objective is to position one country in the region within the implication of the Neo-Classical growth model so that its capital inflows surges for an improvement on growth.

For future research avenue, decomposing the net total capital inflows into the sub-flows like the public and private flows, or the debt and the portfolio flows would be important extensions. For instance, we can separate the public and private flows by allowing the government to issue the debt to finance the public expenditure.

\section{References}

Alfaro, Laura, Sebnem KalemliOzcan, and Vadym Volosovych. "Sovereigns, upstream capital flows, and global imbalances." Journal of the European Economic Association 12.5 (2014): 1240-1284.

Aguiar, Mark, and Manuel Amador. "Growth in the Shadow of Expropriation." The Quarterly Journal of Economics 126.2 (2011): 651-697.

Benhima, Kenza. "A reappraisal of the allocation puzzle through the portfolio approach." Journal of international Economics 89.2 (2013): 331-346.

Bernanke, Ben S. "The global saving glut and the US current account deficit". No. 77. 2005.

Boyd, John H., and Bruce D. Smith. "Capital market imperfections, international credit markets, and nonconvergence." Journal of Economic theory 73.2 (1997): 335-364.

Caselli, Francesco, and James Feyrer. "The Marginal Product of Capital." The Quarterly Journal of Economics (2007): 535-568.

Coeurdacier, Nicolas, Stphane Guibaud, and Keyu Jin. "Credit constraints and growth in a global economy." The American Economic Review 105.9 (2015): 2838-2881.

Farhi, Emmanuel, Ricardo Caballero, and Pierre-Olivier Gourinchas. "An Equilibrium Model of Global Imbalances and Low Interest Rates." American Economic Review 98.1 (2008).

Gertler, Mark, and Kenneth Rogoff. "North-South lending and endogenous domestic capital market inefficiencies." Journal of monetary Economics 26.2 (1990): 245-266.

Gourinchas, Pierre-Olivier, and Hélène Rey. "External Adjustment, Global Imbalances, Valuation Effects." Handbook of International Economics 4 (2014): 585-645.

Gourinchas, Pierre-Olivier, and Olivier Jeanne. "Capital flows to developing countries: The allocation puzzle." The Review of Economic Studies (2013): rdt004.

Kraay, Aart, and Jaume Ventura. "Current accounts in debtor and creditor countries." The Quarterly Journal of Economics 115.4 (2000): 1137-1166. 
Lucas, Robert E. "Why doesn't capital flow from rich to poor countries?." The American Economic Review 80.2 (1990): 92-96.

Matsuyama, Kiminori. "Financial Market Globalization, SymmetryBreaking, and Endogenous Inequality of Nations." Econometrica 72.3 (2004): 853-884.

Obstfeld, Maurice, and Kenneth S. Rogoff. "Foundations of international macroeconomics". Vol. 30. Cambridge, MA: MIT press, 1996.

Ohanian, Lee E., Paulina Restrepo-Echavarria, and Mark LJ Wright. "Bad Investments and Missed Opportunities? Capital Flows to Asia and Latin America, 1950-2007." University of California Los Angeles (2015).

Prasad, Eswar S., Raghuram G. Rajan, and Arvind Subramanian. Foreign capital and economic growth. No. w13619. National Bureau of Economic Research, 2007.

Solow, Robert M. "A contribution to the theory of economic growth." The quarterly journal of economics 70.1 (1956): 65-94.

Swan, Trevor W. "Economic growth and capital accumulation." Economic record 32.2 (1956): 334-361.

\section{Appendix}

\section{A Definition of Equilibrium}

\section{Definition A.0.1. The autarky temporal equilibrium.}

Given the value determined by the last period $\left(S_{t-1}\right)$, the exogenous variable $\left(A_{t}, N_{t}\right)$, and the expected interest rate with perfect foresight $\left(R_{t+1}^{l}\right)$, the temporary equilibrium is a list of prices $\left(R_{t}^{l}, R_{t}^{d}, R_{t}, w_{t}\right)$ and allocations $\left(c_{t}^{y}, c_{t}^{o}, s_{t}, I_{t}\right)$, aggregate variables $\left(K_{t}, S_{t}, L_{t}, Y_{t}\right)$ such that :

1. Profit is maximized and Utility is maximized subjected to budget constraint.

2. Market clearing conditions are satisfied:

a Labor market: $L_{t}=N_{t}$

b Capital market: $K_{t}=S_{t-1}=N_{t-1} s_{t-1}$

$c$ Good market: $N_{t} c_{t}^{y}+N_{t} s_{t}+N_{t-1} c_{t}^{o}=Y_{t}$

Definition A.0.2. The autarky inter-temporal equilibrium.

Given an initial lending interest rate $\left(R_{t=0}^{l}\right)$, an inter-temporal equilibrium with perfect foresight is a sequence of temporary equilibria that satisfies for all $(t>0)$ the conditions that:

$$
\begin{aligned}
k\left(R_{t+1}^{l}, \gamma\right) & =s\left(R_{t}^{l}, R_{t+1}^{l}, \tau, \gamma\right) \\
\Leftrightarrow\left(\frac{\alpha(1-\gamma)}{R_{t+1}^{l}}\right)^{1 /(1-\alpha)} & =\frac{(1-\alpha)(\alpha(1-\gamma))^{\alpha /(1-\alpha)} \beta(1-\tau)}{(1+\beta(1-\tau))\left(R_{t}^{l}\right)^{\alpha /(1-\alpha)}} \frac{1}{\left(1+g_{t+1}^{A}\right)\left(1+g_{t+1}^{N}\right)}-\frac{\gamma \alpha[\alpha(1-\gamma)]^{\alpha /(1-\alpha)}}{(1+\beta(1-\tau))\left(R_{t+1}^{l}\right)^{1 /(1-\alpha)}}
\end{aligned}
$$




\section{Definition A.0.3. The integration temporal equilibrium.}

For country $(j)$ in two-country economy, given the value determined by the last period $\left(S_{t-1}^{j}\right)$, the exogenous variable $\left(A_{t}^{j}, N_{t}^{j}\right)$, and the expected world interest rate with perfect foresight $\left(R_{t+1}^{l, w}\right)$, the temporary equilibrium is a list of price $\left(R_{t}^{l, w}, R_{t}^{d, j}, R_{t}^{j}, w_{t}^{j}\right)$ and allocations $\left(c_{t}^{y, j}, c_{t}^{o, j}, s_{t}^{j}, I_{t}^{j}\right)$, aggregate variables $\left(K_{t}^{j}, S_{t}^{j}, L_{t}^{j}, Y_{t}^{j}\right)$ in each country $j$ such that :

1. Profit is maximized and Utility is maximized subjected to budget constraint.

2. Market clearing conditions are satisfied:

a Labor market : $L_{t}^{D, j}=N_{t}^{j}$

$b$ World capital market: $\Sigma_{j} K_{t}^{j}=\Sigma_{j} S_{t-1}^{j} \equiv \Sigma_{j} N_{t-1}^{j} s_{t-1}^{j}$

c World good market: $\Sigma_{j}\left(N_{t}^{j} c_{t}^{y, j}+N_{t}^{j} s_{t}^{j}+N_{t-1}^{j} c_{t}^{o, j}\right)=\Sigma_{j} Y_{t}^{j}$

\section{Definition A.0.4. The integration inter-temporal equilibrium.}

For country $j$ in two-country economy, given an initial world lending interest rate $\left(R_{t=0}^{l, w}\right)$, an intertemporal equilibrium with perfect foresight is a sequence of temporary equilibria that satisfies for all $t>0$ the conditions:

$$
\Sigma_{j} \frac{A_{t}^{j} N_{t}^{j}}{\Sigma_{j} A_{t}^{j} N_{t}^{j}} k\left(R_{t+1}^{l, w}, \gamma^{j}\right)=\Sigma_{j} \frac{A_{t}^{j} N_{t}^{j}}{\Sigma_{j} A_{t}^{j} N_{t}^{j}} s\left(R_{t}^{l, w}, R_{t+1}^{l, w}, \tau^{j}, \gamma^{j}\right)
$$

whereby, $k\left(R_{t+1}^{l, w}, \gamma^{j}\right) \equiv \frac{K_{t+1}^{j}}{A_{t}^{j} N_{t}^{j}} ; s\left(R_{t}^{l, w}, R_{t+1}^{l, w}, \tau^{j}, \gamma^{j}\right) \equiv \frac{S_{t}^{j}}{A_{t}^{j} N_{t}^{j}}$.

\section{B Proofs}

\section{Theorem 2.2.1}

Proof. We define the function $\Delta\left(R_{t+1}^{l}, R_{t}^{l}\right)$ as following:

$$
\begin{aligned}
& \Delta\left(R_{t+1}^{l}, R_{t}^{l}\right) \equiv k\left(R_{t+1}^{l}, \gamma\right)-s\left(R_{t+1}^{l}, R_{t}^{l}, \tau, \gamma\right) \\
= & {\left[(\alpha(1-\gamma))^{1 /(1-\alpha)}+\frac{\gamma \alpha[\alpha(1-\gamma)]^{\alpha /(1-\alpha)}}{1+\beta(1-\tau)}\right] \frac{\left(1+g_{t+1}^{A}\right)\left(1+g_{t+1}^{N}\right)}{\left(R_{t+1}^{l}\right)^{1 /(1-\alpha)}}-\frac{(1-\alpha)(\alpha(1-\gamma))^{\alpha /(1-\alpha)} \beta(1-\tau)}{1+\beta(1-\tau)} \frac{1}{\left(R_{t}^{l}\right)^{\alpha /(1-\alpha)}} }
\end{aligned}
$$

1 Existence of steady state.

$\lim _{R_{t+1}^{l} \rightarrow 0} \Delta\left(R_{t+1}^{l}, R_{t}^{l}\right)>0$ and $\lim _{R_{t+1}^{l} \rightarrow \infty} \Delta\left(R_{t+1}^{l}, R_{t}^{l}\right)<0$

2 Uniqueness and Global stability.

Since $\frac{\partial \Delta\left(R_{t+1}^{l}, R_{t}^{l}\right)}{\partial R_{t+1}^{l}} \neq 0, R_{t+1}^{l}$ is an implicit function of $R_{t}^{l}$, denoted by: $R_{t+1}^{l}=h\left(R_{t}^{l}\right)$. By the implicit function theorem, $\frac{\partial R_{t+1}^{l}}{\partial R_{t}^{l}}>0$, since:

$$
\begin{aligned}
\frac{\partial \Delta}{\partial R_{t+1}^{l}} & =-\left[(\alpha(1-\gamma))^{1 /(1-\alpha)}+\frac{\gamma \alpha[\alpha(1-\gamma)]^{\alpha /(1-\alpha)}}{1+\beta(1-\tau)}\right] \frac{\left(1+g_{t+1}^{A}\right)\left(1+g_{t+1}^{N}\right)}{(1-\alpha)\left(R_{t+1}^{l}\right)^{(2-\alpha) /(1-\alpha)}}<0 \\
\frac{\partial \Delta}{\partial R_{t}^{l}} & =\frac{\alpha(\alpha(1-\gamma))^{\alpha /(1-\alpha)} \beta(1-\tau)}{1+\beta(1-\tau)} \frac{1}{\left(R_{t}^{l}\right)^{1 /(1-\alpha)}}>0
\end{aligned}
$$


Therefore, $h\left(R_{t}^{l}\right)$ is a monotonic increasing function, and converges to one positive value if any. By l'Hôpital rule, the graph of $h\left(R_{t}^{l}\right)$ would be below the 45 degree line for a large enough value of $R_{t}^{l}$.

$$
\lim _{R_{t}^{l} \rightarrow \infty} \frac{R_{t+1}^{l}}{R_{t}^{l}}=0<1
$$

In sum, $R_{t+1}^{l}=h\left(R_{t}^{l}\right)$ is both monotonic increasing and concave function. Then, it would converge to one finite positive value $0<R^{l}<\infty$. The comparative statics are easy to derive since we have a closed form solution for the interest rate for $\sigma=1$.

\section{Theorem 2.2 .2}

Proof. For country $j$ in two-country economy, we define the function $\Delta\left(R_{t+1}^{l, w}, R_{t}^{l, w}\right)$ as following:

$$
\begin{aligned}
& \Delta\left(R_{t+1}^{l, w}, R_{t}^{l, w}\right) \equiv \Sigma_{j} \frac{A_{t}^{j} N_{t}^{j}}{\Sigma_{j} A_{t}^{j} N_{t}^{j}} k\left(R_{t+1}^{l, w}, \gamma^{j}\right)-\Sigma_{j} \frac{A_{t}^{j} N_{t}^{j}}{\Sigma_{j} A_{t}^{j} N_{t}^{j}} s\left(R_{t}^{l, w}, R_{t+1}^{l, w}, \tau^{j}, \gamma^{j}\right) \\
= & \left(\frac{1}{R_{t+1}^{l, w}}\right)^{1 /(1-\alpha)} \Sigma_{j} \frac{A_{t}^{j} N_{t}^{j}}{\Sigma_{j} A_{t}^{j} N_{t}^{j}}\left[\left(\alpha\left(1-\gamma^{j}\right)\right)^{1 /(1-\alpha)}+\frac{\left.\gamma^{j} \alpha\left[\alpha\left(1-\gamma^{j}\right)\right]^{\alpha /(1-\alpha)}\right]}{1+\beta\left(1-\tau^{j}\right)}\right]\left(1+g_{t+1}^{A, j}\right)\left(1+g_{t+1}^{N, j}\right) \\
- & \left(\frac{1}{R_{t}^{l, w}}\right)^{\alpha /(1-\alpha)} \Sigma_{j} \frac{A_{t}^{j} N_{t}^{j}}{\Sigma_{j} A_{t}^{j} N_{t}^{j}} \frac{(1-\alpha)(\alpha(1-\gamma))^{\alpha /(1-\alpha)} \beta\left(1-\tau^{j}\right)}{\left(1+\beta\left(1-\tau^{j}\right)\right)}
\end{aligned}
$$

\section{Existence of steady state.}

$\lim _{R_{t+1}^{l, w} \rightarrow 0} \Delta\left(R_{t+1}^{l, w}, R_{t}^{l, w}\right)>0$ and $\lim _{R_{t+1}^{l, w} \rightarrow \infty} \Delta\left(R_{t+1}^{l, w}, R_{t}^{l, w}\right)<0$

\section{Uniqueness and Global stability.}

Since $\frac{\partial \Delta\left(R_{t+1}^{l, w}, R_{t}^{l, w}\right)}{\partial R_{t+1}^{l, w}} \neq 0$, then $R_{t+1}^{l, w}$ is a function of $R_{t}^{l, w}: R_{t+1}^{l, w} \equiv h\left(R_{t}^{l, w}\right)$.

By the implicit function theorem, $\frac{\partial \Delta}{\partial R_{t+1}^{l, w}}<0$ and $\frac{\partial \Delta}{\partial R_{t}^{l, w}}>0$. Then, $\frac{\partial R_{t+1}^{l, w}}{\partial R_{t}^{l, w}}>0$. Therefore, $h\left(R_{t}^{l, w}\right)$ is a monotonic increasing function, and it would converge to one positive value if any.

Moreover, by l'Hôpital rule,

$$
\lim _{R_{t}^{l, w} \rightarrow \infty} \frac{R_{t+1}^{l, w}}{R_{t}^{l, w}}=0<1
$$

In sum, $R_{t+1}^{l, w}=h\left(R_{t}^{l, w}\right)$ is both monotonic increasing and concave function since its graph would be below the 45 degree line for a large enough value of $R_{t}^{l, w}$. Then, it would converge to one finite positive value $0<R^{l, w}<\infty$.

For the case of symmetric growth rate across countries, $\lambda_{t}^{j} \equiv \frac{Y_{t}^{j}}{Y_{t}^{w}}, \theta_{t}^{j} \equiv \frac{\lambda_{t}^{j} \vartheta^{j}}{\bar{\vartheta}}$,

$$
\begin{aligned}
R_{t}^{l, w} & =\frac{\alpha}{(1-\alpha)} \frac{Y_{t}^{w}}{Y_{t-1}^{w}}\left(\frac{\Sigma_{j} \lambda_{t}^{j}\left[\mu\left(\gamma^{j}, \tau^{j}\right)+1-\gamma^{j}\right]}{\bar{\vartheta}}\right)=\frac{\alpha}{(1-\alpha)} \frac{Y_{t}^{w}}{Y_{t-1}^{w}} \Sigma_{j} \lambda_{t}^{j} \frac{\vartheta^{j}}{\bar{\vartheta}}\left(\frac{\left[\mu\left(\gamma^{j}, \tau^{j}\right)+1-\gamma^{j}\right]}{\vartheta^{j}}\right) \\
& =\frac{\alpha}{(1-\alpha)} \frac{Y_{t}^{w}}{Y_{t-1}^{w}} \Sigma_{j} \theta_{t}^{j}\left(\frac{\left[\mu\left(\gamma^{j}, \tau^{j}\right)+1-\gamma^{j}\right]}{\vartheta^{j}}\right)=\Sigma_{j} \theta_{t}^{j} R_{t}^{l, j}
\end{aligned}
$$

Therefore, $\min _{j} R_{t}^{l, j}<R_{t}^{l, w}<\max _{j} R_{t}^{l, j}$. 


\section{CRRA Utility}

We show that, with general utility function, the main mechanism that equilibrium interest rate is increasing on saving wedge still holds. Therefore, the use of log-utility on the main text is validated.

In particular, we employ the standard isoelastic preferences $u(c)=\left(c^{1-1 / \sigma}-1\right) /(1-1 / \sigma)$ where $\sigma$ is the intertemporal elasticity of substitution coefficient. The Euler equation gives the saving function by the young agent.

$$
\frac{u^{\prime}\left(c_{t}^{y}\right)}{u^{\prime}\left(c_{t+1}^{o}\right)}=\beta(1-\tau) R_{t+1}^{l} \Rightarrow s_{t}=\frac{w_{t}-\left(\beta(1-\tau) R_{t+1}^{l}\right)^{-\sigma} z_{t+1}}{1+\beta^{-\sigma}\left((1-\tau) R_{t+1}^{l}\right)^{(1-\sigma)}}
$$

Using the income transfer (6), the shares over output by labor income $\left(w_{t} N_{t}=(1-\alpha) Y_{t}\right)$ and by capital income $\left(R_{t+1} I_{t+1}=R_{t+1} K_{t+1}=\alpha Y_{t+1}\right)$, we end up with the total savings at equilibrium.

$$
S_{t}=N_{t} s_{t}=\frac{(1-\alpha) Y_{t}-\left[\beta(1-\tau) R_{t+1}^{l}\right]^{-\sigma} \gamma \alpha Y_{t+1}}{1+[\beta(1-\tau)]^{-\sigma}\left(R_{t+1}^{l}\right)^{(1-\sigma)}}
$$

With the income transfer by the government, the saving wedge enters the saving-output ratio $\left(S_{t} / Y_{t}\right)$ with the power $(-\sigma)$. Therefore, given the output growth rate $\left(Y_{t+1} / Y_{t}\right)$, the saving rate is always decreasing on level of saving wedge. As a result, one country with a lower saving wedge would have a higher saving rate. Since the saving-output ratio is decreasing on the saving wedge for all values of the inter-temporal elasticity of substitution coefficient while the investment-output ratio is independent to the inter-temporal elasticity of substitution coefficient, we can focus on the case of log utility $(\sigma=1)$ without losing generality.

The positive impact of saving wedge on lending interest rate relies on the modeling of capital taxation. In the set-up where the income taxation is transfer to the households, a higher saving wedge reduces the savings, then raises the lending interest rate, even on the case of more general isoelastic utility function. Indeed, by the equation (C.1) at the partial equilibrium, the wedge affects the deposit interest rate and then, the saving through the substitution and income effect. A higher wedge decreases the deposit rate, which, in turn, reduces the saving by the substitution effect but raises the saving by the income effect. Therefore, the role of wedge on saving depends on the value of the inter-temporal substitution coefficient $(\sigma)$. In general equilibrium with the taxation income being transferred to households, the income effect disappears. Then, only substitution effect works: a higher wedge curtails the saving and raises the lending interest rate, given the investment demand.

However, when the taxation income is used to finance public expenditure, the relationship between saving and taxation depends on the value of $(\sigma)$. In online Appendix, we show that with public expenditure and for $0<\sigma<1$, the income effect wins the substitution effect. On that case, the interest rate is decreasing on saving wedge because a higher saving wedge raises the saving supply, which reduces the autarky interest rate, given the investment demand. 